\title{
The APPliCation Of THERMOGRAPHIC DiagnOSTIC In InVESTMent CASTing Process
}

\author{
Ondřej Vrátný, Aleš Herman \& Irena Kubelková
}
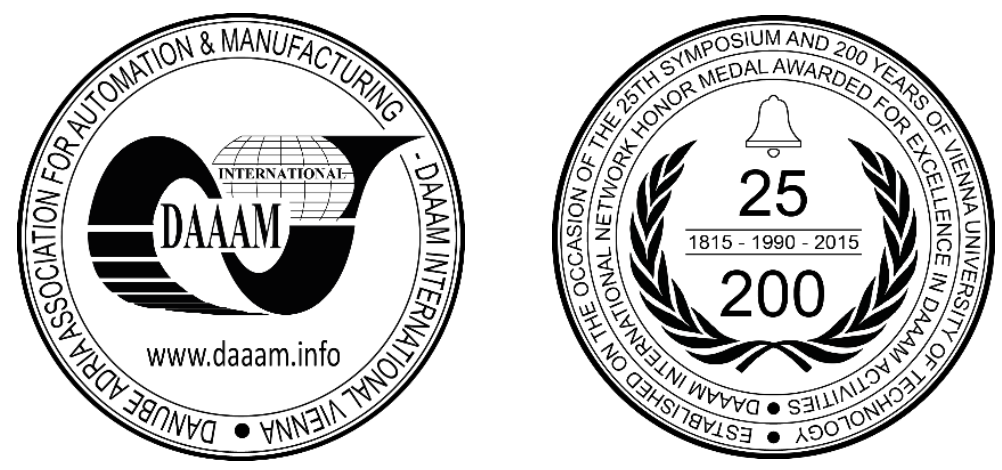

This Publication has to be referred as: Vratny, O[ndrej]; Herman, A[les] \& Kubelkova, I[rena] (2017). The Application Of Thermographic Diagnostic In Investment Casting Process, Proceedings of the 28th DAAAM International Symposium, pp.1118-1125, B. Katalinic (Ed.), Published by DAAAM International, ISBN 978-3-902734-11-2, ISSN 1726-9679, Vienna, Austria

DOI: $10.2507 / 28$ th.daaam.proceedings.156

\begin{abstract}
The paper aims to describe the dependence of cooling rate of a ceramic shell on the number of refractory slurries and on the way of insulation in investment casting process. The infrared thermography was the basis for measurement of temperatures during experiments. This method has not been used during Investment Casting process yet according to scientific databases. From a plenty of experiments there are shown the top results in this paper. The point was to investigate the cooling behaviour of ceramic shell to find out the dependence of a decreasing temperature on time. This knowledge is essential in determining the maximum period of time to assure the minimum required preheating temperature of the ceramic shell.
\end{abstract}

Keywords: Thermographic analysis; Investment casting; Ceramic shell; A Cooling rate

\section{Introduction}

The goal of the paper is an investigation of behaviour of ceramic shell in investment casting process from a cooling point of view. There are not many articles dealing with the issue of thermographic analysis in the casting process. Some authors investigated the cooling behaviour of the mould after the liquid metal had been poured in. [1,8]

Thermographic cameras based on infrared thermography method usually detect radiation in the long-infrared range of the electromagnetic spectrum (approximately 9,000 - 14,000 $\mathrm{nm}$ or 9-14 $\mu \mathrm{m}$ ) and produce images of that radiation, called thermograms. Since infrared radiation is emitted by all objects with a temperature above absolute zero according to the black body radiation law, thermography makes it possible to see one's environment with or without visible illumination. [2, 7, 9, 10]. Investigation of cooling behaviour in casting process is nothing new. Eric Wulf and his colleagues were investigating the influence of different cooling rates in-situ and ex-situ. The temperatures of the geometric specimens were determined during the experiment with the aid of a near-infrared camera and thermocouples. The aim was to both determine a function between the specimen's cooling rate and the speed of the solid-liquid interface as well as establish a relationship between the thermographic images and the solidification's morphology. [1]

The new idea of the paper is to investigate the cooling behaviour using IRT in Investment casting process, especially to carry out temperature measurements of the ceramic shell after being removed from the preheating furnace.

It is a request from foundries to estimate the shell temperature after a certain period of time since pulling out of the preheating furnace. 
This knowledge is very important in determining the maximum period of time to assure the minimum required preheating temperature of the ceramic shell. If the casting process is delayed, there should be a strict time limit after which the shell has to be return back to the preheating furnace. The minimum preheating temperature is determined by a technologist or by a metallurgist. $[3,4,5,6]$

\section{Experimental part}

Following calibrated devices and equipment were used for measurement:

- Thermographic camera FLIR T640 + evaluation software TOOLS+

- Contact thermometer Ahlborn Therm 2420 with thermocouple FT 106

- Stopwatch

- Tape measure

In the case of uninsulated shell there were used only parameters related to ceramic material. It means especially the value of emissivity $=0,97$. The rest of changeable values were set the same for all measurement (apparent reflected temperature $=30{ }^{\circ} \mathrm{C}$, distance $\left.=2 \mathrm{~m}\right)$.

To all points of the figures in this paper there are assigned the same following parameters:

\begin{tabular}{|l|c|c|}
\hline \multirow{4}{*}{ Ceramic shell $(\mathbf{Z r}+)$} & Emissivity & 0,97 \\
\cline { 2 - 3 } & Apparent reflected temperature & $30{ }^{\circ} \mathrm{C}$ \\
\cline { 2 - 3 } & Distance & $2 \mathrm{~m}$ \\
\hline \multirow{3}{*}{ Insulation (Sibral) } & Emissivity & 0,36 \\
\cline { 2 - 3 } & Apparent reflected temperature & $30^{\circ} \mathrm{C}$ \\
\cline { 2 - 3 } & Distance & $2 \mathrm{~m}$ \\
\hline
\end{tabular}

Table 1. Set parameters for thermographic analysis

\subsection{The cooling process of ceramic shell A}

The measurement of cooling rate of ceramic shell $A$ was executed in two variants.

- $\quad$ First, the mould was as fast as possible transported from the preheating furnace to the bottom chamber of vacuum furnace to simulate real casting conditions. The bottom chamber was immediately closed and the space was evacuated. In this case, vacuum does not refer to a state where there is no atmosphere at all (absolute vacuum), but rather, is simply a specific space where the gas pressure is less than atmospheric pressure. As a result, the degree or level of vacuum is quantified in terms of pressure (this case $p=10^{-6}$ bar). Three thermal images were captured. First one after taking the mould out of preheating furnace, second one just before place to the chamber of vacuum furnace and the last thermal image (as it is shown in the figure 1) is taken immediately after being removed from the chamber. It took 251 seconds since removing the ceramic mould from the preheating furnace to opening the vacuum furnace. The temperature decreased from $1085{ }^{\circ} \mathrm{C}$ to $668{ }^{\circ} \mathrm{C}$, it means that the ceramic shell cooled down by $417^{\circ} \mathrm{C}$.

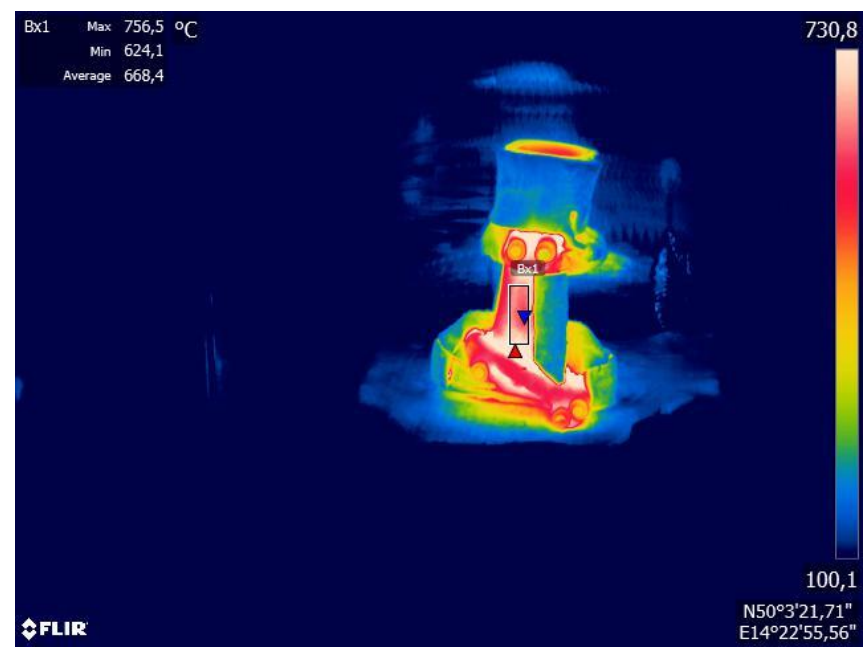

Fig. 1. The thermal image of ceramic shell $A$ 
- Second measurement was recorded using thermographic camera. The record was created in sequence after 2 seconds. The evaluated part of the shell was as in the vacuum furnace trailing edge of a blade. In the Table 2 there are temperature values related to this area depending on time.

\begin{tabular}{|c|c|c|c|}
\hline \multicolumn{4}{|c|}{ Cooling rate of the ceramic shell $\boldsymbol{A}$ - 13 slurries } \\
\hline Time [s] & Temperature $\left[{ }^{\circ} \mathbf{C}\right.$ ] & Time period [s] & Average decrease $\left[{ }^{\circ} \mathbf{C} / \mathbf{s}\right.$ ] \\
\hline 30 & 900,58 & 2 to 30 & 4,76 \\
\hline 60 & 843,87 & 31 to 60 & 1,89 \\
\hline 90 & 802,88 & 61 to 90 & 1,37 \\
\hline 120 & 766,84 & 91 to 120 & 1,20 \\
\hline 150 & 740,38 & 121 to 150 & 0,88 \\
\hline 180 & 722,41 & 151 to 180 & 0,60 \\
\hline 210 & 701,49 & 181 to 210 & 0,70 \\
\hline 240 & 683,71 & 211 to 240 & 0,59 \\
\hline
\end{tabular}

Table 2. The cooling rate of the ceramic shell $A$

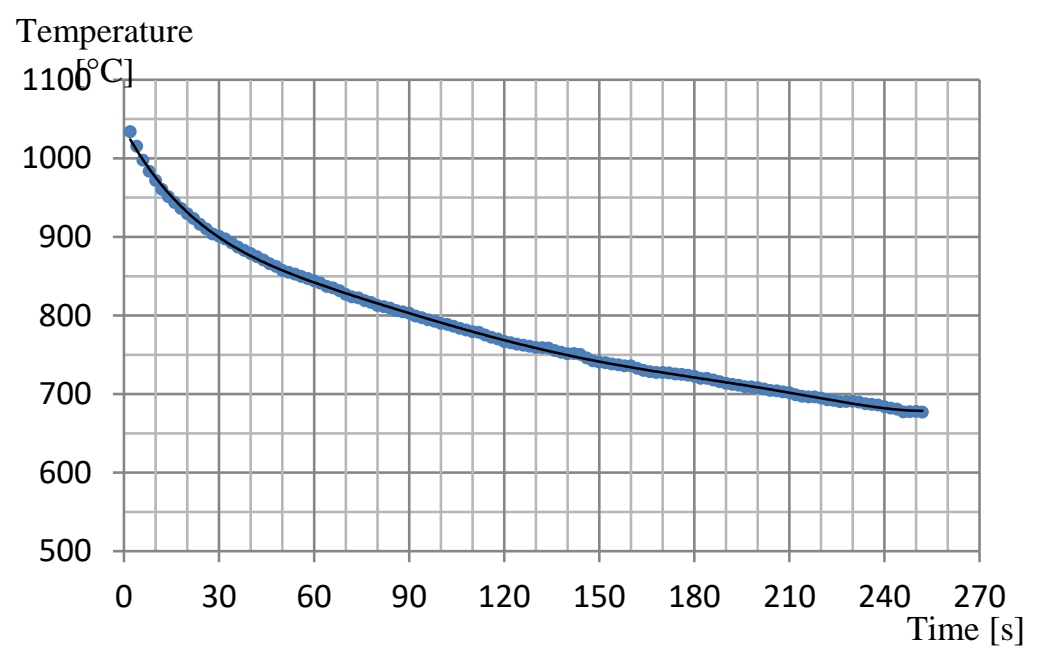

Fig. 2. The cooling rate of ceramic shell $A$

The following graph in Fig. 3 shows the comparison between cooling under vacuum and cooling in the surrounding atmosphere. Despite the different number of measurement we can make a conclusion, that the temperature values are almost the same at the time of 251 second after the ceramic shell is removed from the preheating furnace. In the case of cooling in the vacuum chamber there is the temperature value $688^{\circ} \mathrm{C}$ and during the cooling in atmosphere the temperature decreased to $677^{\circ} \mathrm{C}$. The preheating temperature was the same in both cases. We may say, that the cooling process under vacuum and in the atmosphere have similar character.

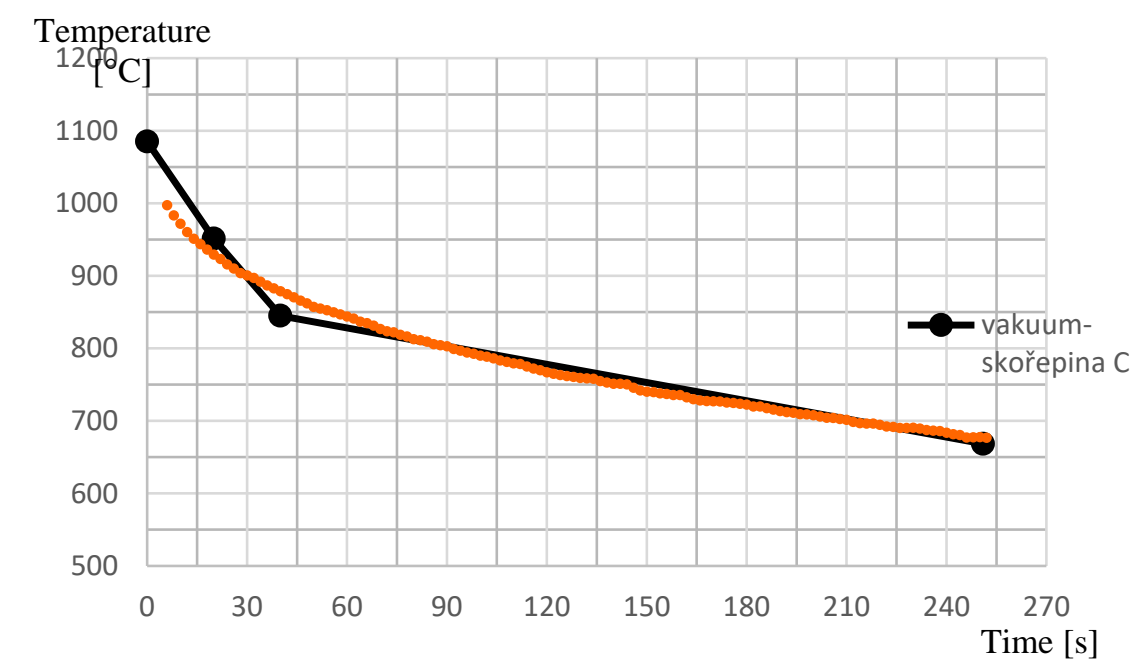

Fig. 3. The comparison of cooling process under vacuum and in the atmosphere 


\subsection{The cooling process of the ceramic shell $B$}

The ceramic shell $B$ was cooled down in the surrounding atmosphere from the temperature of $1100{ }^{\circ} \mathrm{C}$ and evaluated in two areas indicated in Fig. 4. First area was around root part, marked as $B x 1$ and the area $B x 2$ was placed near to pouring basin.

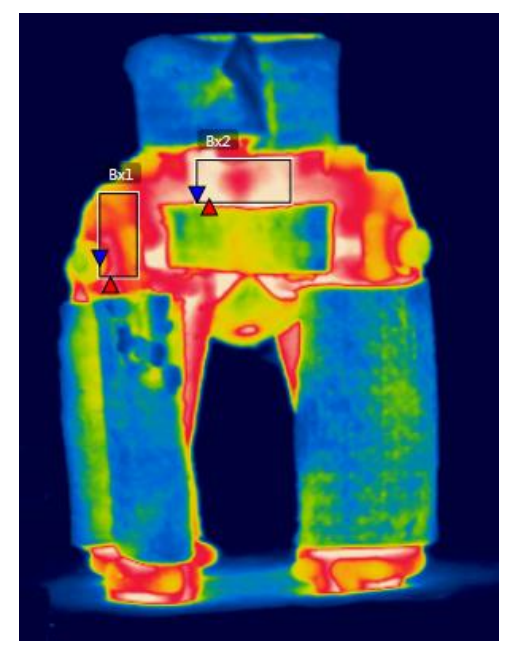

Fig. 4. The thermal image of ceramic shell $B$

In the Table 3 there is a list of values of temperature depending on time for cooling process of the ceramic shell $B$.

\begin{tabular}{|c|c|c|c|c|c|c|c|}
\hline \multicolumn{8}{|c|}{ Cooling rate of the ceramic shell $\boldsymbol{B}$ - 12 slurries } \\
\hline \multicolumn{3}{|c|}{ The area under the pouring basin } & \multicolumn{5}{c|}{ The area around root } \\
\hline $\begin{array}{c}\text { Time } \\
{[\mathbf{s}]}\end{array}$ & $\begin{array}{c}\text { Temperature } \\
{\left[{ }^{\circ} \mathbf{C}\right]}\end{array}$ & $\begin{array}{c}\text { Time period } \\
{[\mathbf{s}]}\end{array}$ & $\begin{array}{c}\text { Average } \\
\text { decrease } \\
{\left[{ }^{\circ} \mathbf{C} / \mathbf{s}\right]}\end{array}$ & $\begin{array}{c}\text { Time } \\
{[\mathbf{s}]}\end{array}$ & $\begin{array}{c}\text { Temperature } \\
{\left[\mathbf{C}^{\circ}\right]}\end{array}$ & $\begin{array}{c}\text { Time period } \\
\text { [s] }\end{array}$ & $\begin{array}{c}\text { Average } \\
\text { decrease } \\
{\left[{ }^{\circ} \mathbf{C} / \mathbf{s}\right]}\end{array}$ \\
\hline 30 & 958,88 & 4 to 30 & 4,77 & 30 & 864,93 & 6 to 30 & 5,37 \\
\hline 60 & 878,51 & 31 to 60 & 2,15 & 60 & 784,35 & 31 to 60 & 2,75 \\
\hline 90 & 810,05 & 61 to 90 & 2,91 & 90 & 733,29 & 61 to 90 & 2,03 \\
\hline 120 & 786,29 & 91 to 120 & 1,57 & 120 & 685,60 & 91 to 120 & 1,46 \\
\hline 150 & 746,37 & 121 to 150 & 1,20 & 150 & 646,87 & 121 to 150 & 1,29 \\
\hline 180 & 718,87 & 151 to 180 & 1,21 & 180 & 614,27 & 151 to 180 & 1,09 \\
\hline 210 & 679,31 & 181 to 210 & 0,84 & 210 & 585,10 & 181 to 210 & 0,97 \\
\hline
\end{tabular}

Table 3. The cooling rate of ceramic shell $B$

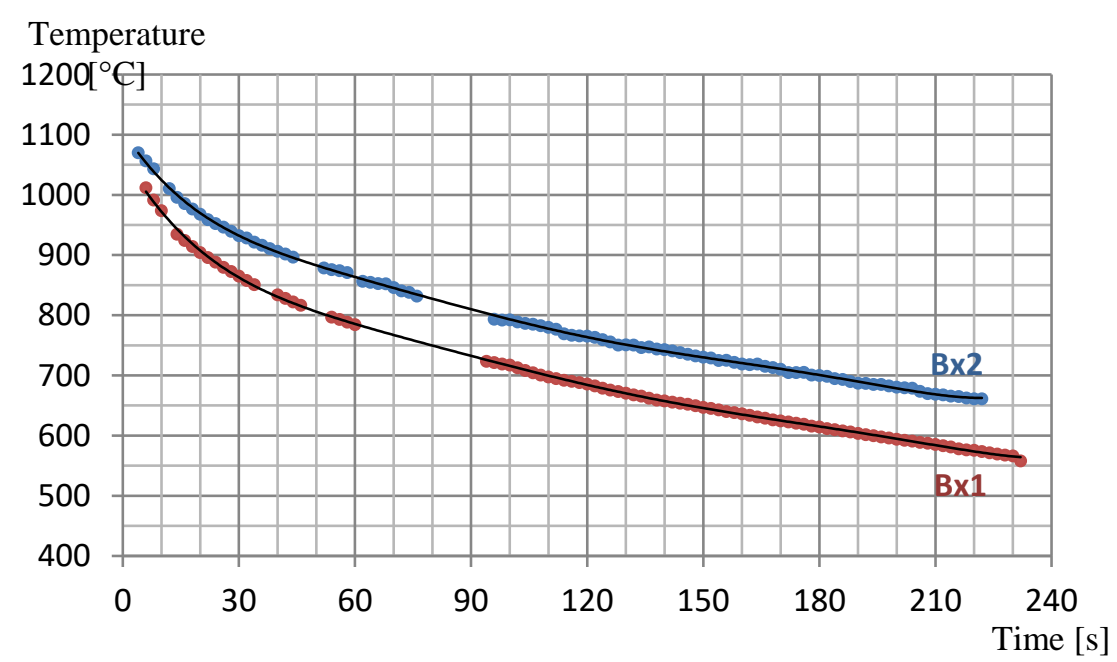

Fig. 5. The cooling rate of ceramic shell $B$ 
From the Fig. 4 is obvious, that area around root is cooled down faster than the area near to pouring basin. The reason is probably thinner shell around the external rounding and the fact, that this area is exhibited to surrounding relatively cold atmosphere. It is an opposite situation in compare to the second evaluated area $B x 2$, where the shape of the ceramic shell is characterized by internal rounding closed to environment and probably thicker shell.

\subsection{The cooling process of the ceramic shell $C$}

The ceramic shell $C$ with 11 slurries was evaluated in area shown in the Fig. 6, this thermal image was captured 4 minutes after being removed from the preheating furnace and shows the differences in temperature between areas near to the warm centre and parts, which are exhibited to environment. The most obvious it is around the top and bottom of pouring basin.

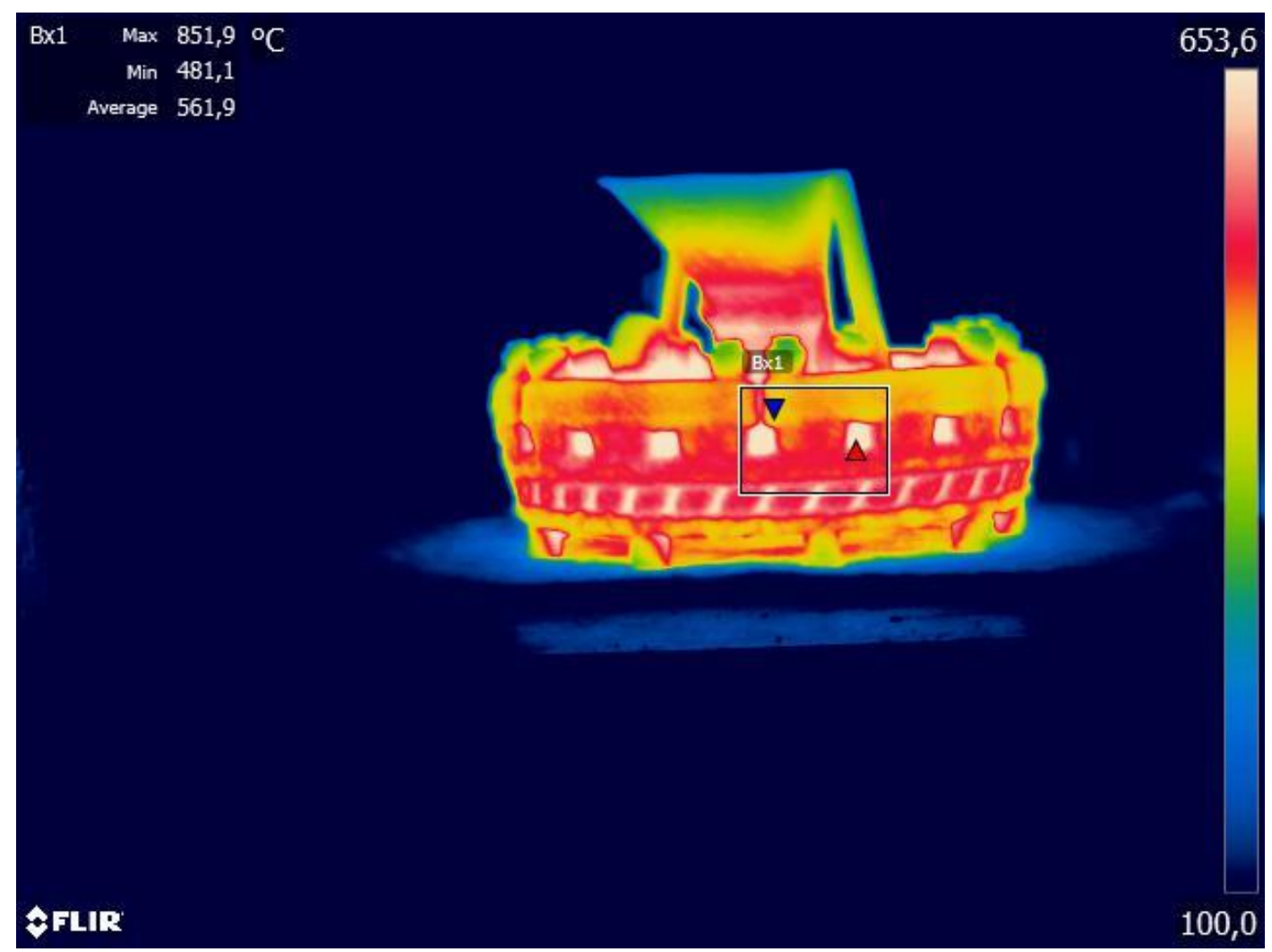

Fig. 6. The thermal image of ceramic shell $C$

In the Table 4 there is a list of values of temperature depending on time for cooling process of the ceramic shell $C$.

\begin{tabular}{|c|c|c|c|}
\hline \multicolumn{4}{|c|}{ Cooling rate of the ceramic shell $\boldsymbol{C}$-11 slurries } \\
\hline Time $[\mathbf{s}]$ & $\begin{array}{c}\text { Temperature } \\
{\left[{ }^{\circ} \mathbf{C}\right]}\end{array}$ & Time period $[\mathbf{s}]$ & Avarage decrease $\left[{ }^{\circ} \mathbf{C} / \mathbf{s}\right]$ \\
\hline 30 & 880,88 & 6 to 30 & 5,47 \\
\hline 60 & 788,10 & 31 to 60 & 3,09 \\
\hline 90 & 732,28 & 61 to 90 & 1,86 \\
\hline 120 & 686,25 & 91 to 120 & 1,53 \\
\hline 150 & 652,32 & 121 to 150 & 1,13 \\
\hline 180 & 616,51 & 151 to 180 & 1,19 \\
\hline 210 & 588,51 & 181 to 210 & 0,93 \\
\hline 240 & 561,93 & 211 to 240 & 0,89 \\
\hline 270 & 541,56 & 241 to 270 & 0,68 \\
\hline 300 & 518,54 & 271 to 300 & 0,77 \\
\hline
\end{tabular}

Table 4. The cooling rate of ceramic shell $C$ 


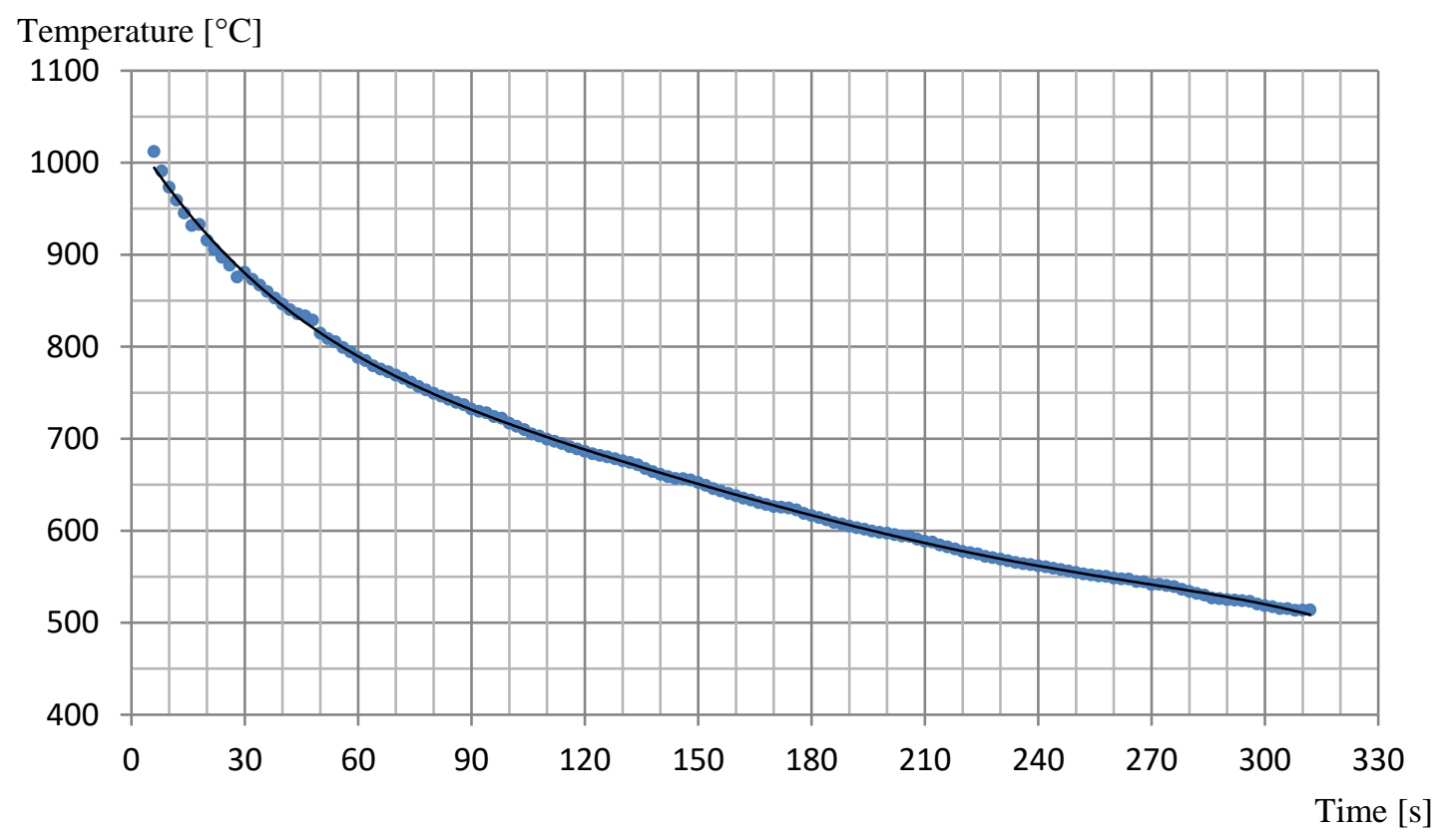

Fig. 7. The cooling rate of ceramic shell $C$

\subsection{The effect of insulation}

In the study of cooling behaviour effected by insulation there were used Sibral wraps with different thickness (13, 25 and $38 \mathrm{~mm}$ ). To eliminate undesirable effect of the shape of ceramic shell there was prepared easy-shape ceramic cylinder which was preheated to the temperature of $1100{ }^{\circ} \mathrm{C}$. This temperature was also the same for all measurements.

The Fig. 8 shows different areas to be evaluated. Based on the knowledge that the ceramic material has the same temperature as the Sibral wrap (through the ceramic shell and insulation should be the same temperature because of heating for more than 3 hours), we were able to match the value of emissivity to the isolation, which was approximately 0,36 .

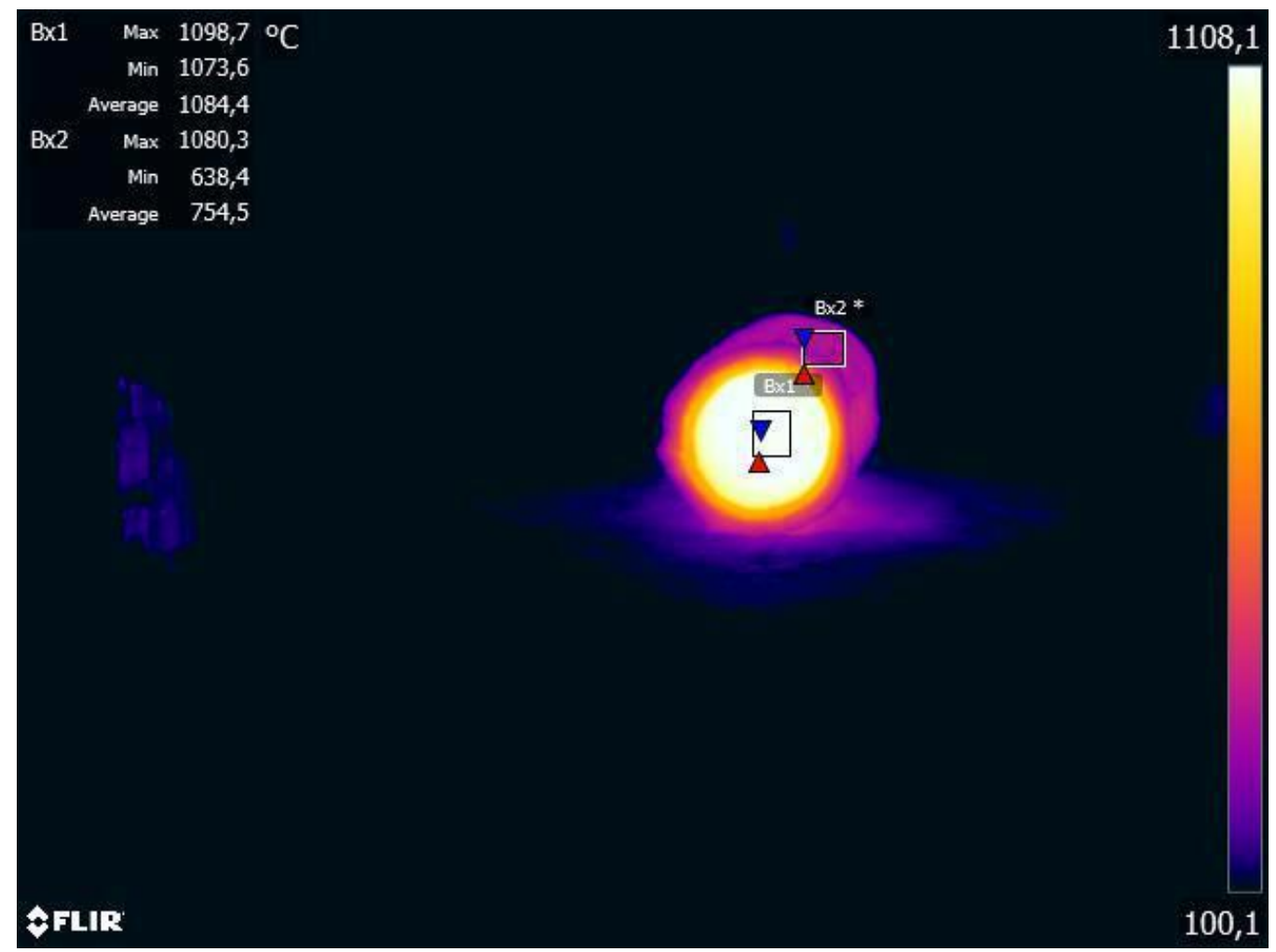

Fig. 8. The evaluation of areas with different value of emissivity 


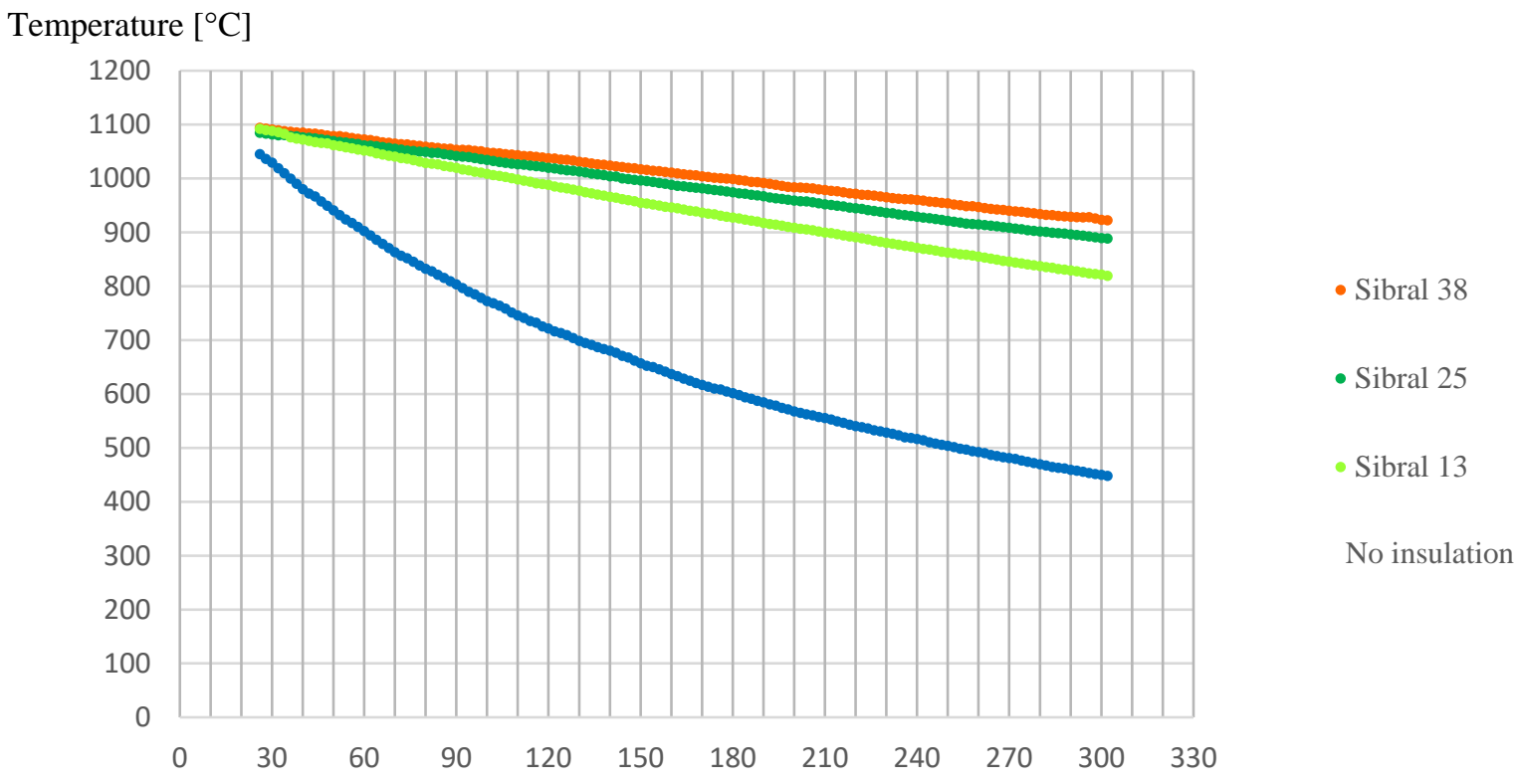

Time $[\mathrm{s}]$

Fig. 9. The cooling rate for wraps of different thickness

\subsection{A comparison of ceramic shells with different number of slurries}

The summary of results related to measurement of cooling process for shells with different number of slurries is shown in the Fig. 10. The temperature goes down slower with increasing number of ceramic layers. After 210 seconds after removing the shell from the preheating furnace there was a temperature of the ceramic shell $D$ with 8 slurries $403{ }^{\circ} \mathrm{C}$, on the opposite side the ceramic shell $A$ with 13 slurries had $701^{\circ} \mathrm{C}$. These 5 ceramic layer difference caused temperature difference of $298{ }^{\circ} \mathrm{C}$. Nevertheless there is almost no difference between the ceramic shell $B\left(12\right.$ slurries $\left.-588{ }^{\circ} \mathrm{C}\right)$ and $C$ $\left(11\right.$ slurries $-585^{\circ} \mathrm{C}$ ). The reason could be in the evaluated areas, which are not comparable with each other. The root area in the case of the ceramic shell $B$ cooled down faster than the area evaluated in the case of the ceramic shell $C$. Anyway the temperature is influenced not only because of number of layers but also because of the shape of shell and different areas, which are exhibited to the environment.

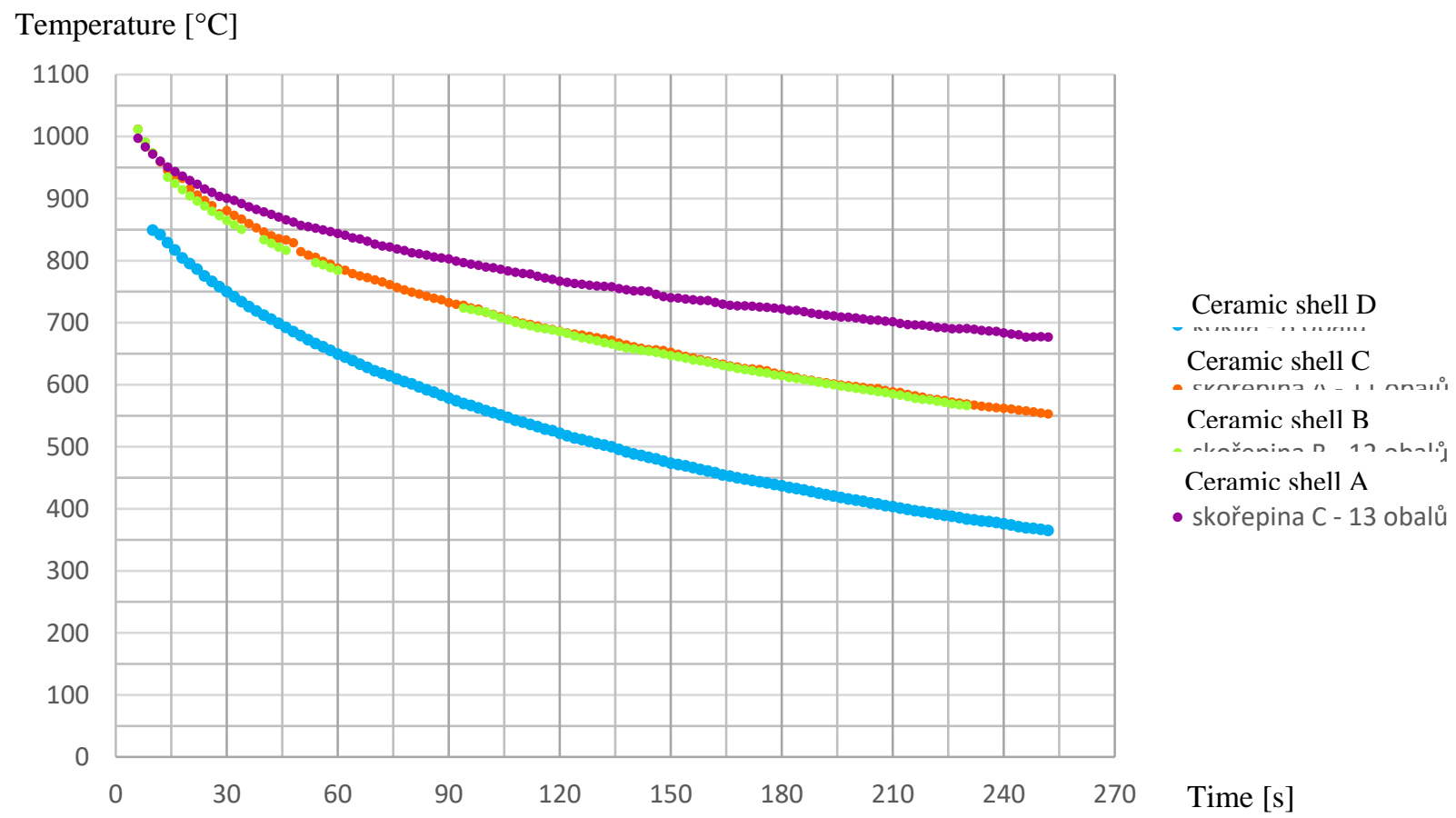

Fig. 10. The cooling rate for shells with different number of slurries 


\section{Conclusion}

The aim of the paper was to investigate the thermal behaviour of ceramic shells used in Investment casting process. The main problem is from the site of foundries to know the maximum period of time the ceramic shell is still allowed to be used. If not, it must be removed back to the preheating furnace.

As a very useful method, as it turned out, was the infrared thermography. Testing was performed using the FLIR T640 thermographic camera, which allowed to take thermal images or videos at the moment of experiments and later evaluation of results. In this experiment the following conclusions were made:

- We may say, that the cooling process under vacuum and in the surrounding atmosphere have similar character.

- For comparison of different shells is very important to choose and evaluate proper area. Every point on the shell has different value of temperature.

- The effect of Sibral heat insulation on the cooling process was investigated. It can be seen from Fig. 9 that when using the smallest thickness of Sibral $13 \mathrm{~mm}$, there is a significant reduction in the cooling rate compared to the uninsulated shell. It is also shown in the graph that the difference between the use of Sibral 13, 25 or 48 depending on temperature is not very important.

- In Fig. 10 is a comparison of the cooling rate depending on the number of slurries. The results show that the increasing number of slurries slow down the cooling rate.

Thermographic analysis is a very useful method in investment casting process. There is a plan to use it to analyse thermal influence on wax pattern deformation and to investigate the whole dipping process in the refractory slurries.

\section{Acknowledgments}

This publication is under the Centre advanced aerospace technologies, reg. No. CZ.02.1.01 / 0.0 / 0.0 / $16 \_019$ / 0000826, which is co-financed by the European Regional Development Fund through the Operational Program Research, development and education.

\section{References}

[1] Wulf, Eric, Christian Krause, Dirk Bormann, Mirko Schaper, Jörg August Becker, Verena Becker a FriedrichWilhelm BACH. (2009) Thermographic analysis of AlSi12 during crystallisation as a function of cooling rate. International Journal of Materials Research [online]. 2009, 100(1), 97-103 [cit. 2017-10-24]. DOI: 10.3139/146.101781. ISSN 1862-5282. Dostupné z: http://www.hanser-elibrary.com/doi/abs/10.3139/146.101781

[2] Helen E. Kourous, Behrouz N. Shabestari, Spencer D. Luster, Jaroslaw P. Sacha, (1998) "Online industrial thermography of die casting tooling using dual-wavelength IR imaging", Proc. SPIE 3361, Thermosense XX, (26 March 1998); doi: 10.1117/12.304731; http://dx.doi.org/10.1117/12.304731

[3] Herman, A.; Vrátný, O.; Kubelková, I., (2016) Vyhodnocení kritických míst na voskových modelech lopatek, Velká Bíteš: PBS Velká Bíteš, 2016. U12133/2016/006.

[4] Herman, A.; Česal, M., (2012) Temperature Stability of the Process of Production of Wax Patterns for Investment Casting Technology, Manufacturing Technology. 2012, 12(12), 108-112. ISSN 1213-2489.

[5] Herman, A.; Česal, M., (2013) The Solving of a Wax Pattern Deformation for the Large Castings of Blades for Gas Turbines, Technolog. 2013,(2), 27-34. ISSN 1337-8996.

[6] Kovanda, K.; Rohan, P.; Herman, A., (2015) Study of Temperature Fields during FCAW Welding, In: Technological forum 2015, 6th International Technical Conference, Book of Proceedings. Jaroměř: Ing. Jan Kudláček, 2015, pp. 211-214. ISBN 978-80-87583-13-5.

[7] Greenberg, A.R., S.S. Shojaie, W.B. Krantz a S.B. Tantekin-Ersolmaz. (1995) Use of infrared thermography for temperature measurement during evaporative casting of thin polymeric films. Journal of Membrane Science [online]. 1995, 107(3), 249-261 [cit. 2017-10-26]. DOI: 10.1016/0376-7388(95)00123-2. ISSN 03767388. Dostupné z: http://linkinghub.elsevier.com/retrieve/pii/0376738895001232 [8] Filaretov, V. \& Adamczak, S. (Year if known). Title of paper, unpublished.

[8] Solórzano, E., F. Garcia-Moreno, N. Babcsán a J. Banhart. (2009) Thermographic Monitoring of Aluminium Foaming Process. Journal of Nondestructive Evaluation [online]. 2009, 28(3-4), 141-148 [cit. 2017-10-26]. DOI: 10.1007/s10921-009-0056-6. ISSN 0195-9298. Dostupné z: http://link.springer.com/10.1007/s10921-009-0056-6

[9] Padalko, A. G., A. N. Veselov a G. V. Talanova. (2008) Thermographic investigation of the phase equilibria in an aluminum-based alloy at high pressures and temperatures. Russian Metallurgy (Metally)[online]. 2008, 2008(5), 413-418 [cit. 2017-10-26]. DOI: 10.1134/S0036029508050091. ISSN 0036-0295. Dostupné z: http://link.springer.com/10.1134/S0036029508050091

[10] Minkina, Waldemar. a Sebastian Dudzik. (2009) Infrared thermography: errors and uncertainties. Hoboken, NJ: J. Wiley, c2009. ISBN 9780470747186. 